\title{
Agriculture and Forest Transition: Understanding of Land Use Change in a Cultural Landscape
}

\author{
José Eduardo dos Santos ${ }^{1}$, Angela Terumi Fushita1, Imyra Maíra Martins de Souza², \\ Lia Martucci Amorim², Valéria Aparecida David Andrade ${ }^{2}$ \\ ${ }^{1}$ Department of Hydrobiology, Federal University of São Carlos, São Carlos, Brazil \\ ${ }^{2}$ Postgraduate Program in Ecology and Natural Resources, Federal Universityof São Carlos, São Carlos, Brazil \\ Email:djes@ufscar.br
}

Received 25 November 2015; accepted 21 December 2015; published 24 December 2015

Copyright (C) 2015 by authors and Scientific Research Publishing Inc.

This work is licensed under the Creative Commons Attribution International License (CC BY). http://creativecommons.org/licenses/by/4.0/

(c) (i) Open Access

\begin{abstract}
Land use trajectory analysis provides both the time and kind of land cover changes to monitor land use dynamics. Land cover change trajectories for three different dates $(1965,1989$ and 2014$)$ extracted from satellite images by vectorization of the thematic information were studied This study was carried out on a cultural landscape (São Carlos municipality, SP, Brazil) with three major land use-cover classes (forest, agriculture and other uses). The results showed the spatiotemporal variability of landscape pattern and forest and agriculture change trajectories. Analysis based on these landscape trajectories demonstrates that agriculture and forest cover changes have been caused by human activities. The results reflect the conflicting interactions between environmental and human systems in the study area. A key question is that the pressure exerted on forest land use-cover depends on the incentives that move society from a conflicting relation with a municipal territory. A more sustainable landscape transition and trajectory for São Carlos municipality are extremely dependent on the regulatory role of the government through strategies related to the implementation of specific categories of legally protected areas (Legal Reserves and Areas of Permanent Preservation).
\end{abstract}

\section{Keywords}

Land Use-Cover, Change Trajectories, Landscape Sustainability, Legally Protected Areas, Remote Sensing

\section{Introduction}

Recent studies have revealed the environmental impacts of land use from global to local scales. These range

How to cite this paper: dos Santos, J.E., Fushita, A.T., de Souza, I.M.M., Amorim, L.M. and Andrade, V.A.D. (2015) Agriculture and Forest Transition: Understanding of Land Use Change in a Cultural Landscape. Open Journal of Applied Sciences, 5, 797-807. http://dx.doi.org/10.4236/ojapps.2015.512076 
from changes in regional climates, changes in carbon and hydrologic cycles, declines in biodiversity through the loss and fragmentation of habitats, degradation of soil and water and overexploitation of native species [1] [2].

Land-use practices are essential for human well-being because they provide natural resources and ecosystem services. On the other hand, these practices can also degrading the ecosystems and services upon which humans depend [3]. This process takes different forms and depends on circumstances, national, regional and local contexts and government policies.

Forest transitions assert that stocks of forest change as societies undergo development, industrialization and urbanization. Changes occur at various scales and may characterize an entire country, a province within a country or a county within a geographical region [4]. The impact of a forest transition on biodiversity varies from place to place and begins during a period of deforestation. Initially, natural areas decline in extent as forested lands are converted into agricultural areas to meet human population demands [5].

Socio-economic activities have been one of the most important factors for land cover change trajectories. In place of temporal series dates of change in satellite images, researchers are now more focused on temporal land cover change trajectories [6].

Trajectory analysis is a new approach for land cover change research based on each pixel in a time series [7] and is developed for long term mapping. Temporal trajectory is using to identify land use trends over time from the relationships among the factors that shape the human-environment relation and their influence within a particular region. The analysis of a land cover trajectory provides the timing and nature of land cover changes and can also provide new information about what kind of land cover change occurred for a landscape [6].

This paper presents land cover change trajectory analysis for forest and agriculture areas and other areas for five decades (1965, 1989 and 2015) throughout São Carlos municipality, São Paulo, Brazil, highlighted the importance of understanding landscape dynamics for sustainability and conservation purposes. This research seeks to (1) determine the spatio-temporal variability of landscape trajectories in the municipal territory and (2) provide evidence as to whether factors revealed by a land cover change trajectory can ensure long-term environmental sustainability by reducing the negative environmental impacts of land use while maintaining ecosystem goods and services.

\section{Material and Methods}

\subsection{Study Area}

The municipality of São Carlos covers an area of $1136.907 \mathrm{~km}^{2}$ and is located in the northeast region of São Paulo state, Brazil, between $47^{\circ} 30^{\prime} \mathrm{W}$ and $48^{\circ} 30^{\prime} \mathrm{W}$ and $21^{\circ} 30^{\prime} \mathrm{S}$ and $22^{\circ} 30^{\prime} \mathrm{S}$. It was selected for study by presenting scenery related to land use fast changes, typical for municipalities located in the northeast region of São Paulo state, Brazil (Figure 1).

According to a demographic census, São Carlos municipality had a total population of 238,958 inhabitants in [9]. Its primary vegetation cover is characterized by semideciduous and riparian forests and various savanna physiognomies with arboreal savanna, sparsely arboreal savanna, and short-shrub savanna. Its maximum altitude is about $950 \mathrm{~m}$ with a minimum of $520 \mathrm{~m}$. The climate of the region is classified between CWA and AW in Köppen's system, representing a transition from warm tropical with dry winter climate to tropical with dry summer and humid winter. The average annual rainfall is $1468 \mathrm{~mm}$, with rain predominating between November and February [8].

\subsection{Methods}

The trajectories of land use changes for the São Carlos (SP) municipality were analyzed over a period of 50 years (1965-2014) based on information from topographic maps for the year 1965 [10] and Landsat imagery for 1989 and 2014. The land use typologies for 1965 were obtained by vectorization of the thematic information from topographic maps of the study area [10]. The land use typologies for 1989 and 2014 were obtained through Landsat images with a pixel size of $30 \times 30 \mathrm{~m}$, collected on October 24, 1989 (TM-5 sensor) and on June 07, 2014 (OLI sensor). The spectral bands 3, 4 and 5 were processed using ENVI 4.7 software, resulting in an R5G4B3 color composition for Landsat imagery. The land use typologies were discriminated by visual interpretation method through on screen digitizing based on tone, texture and context [11] [12]. 


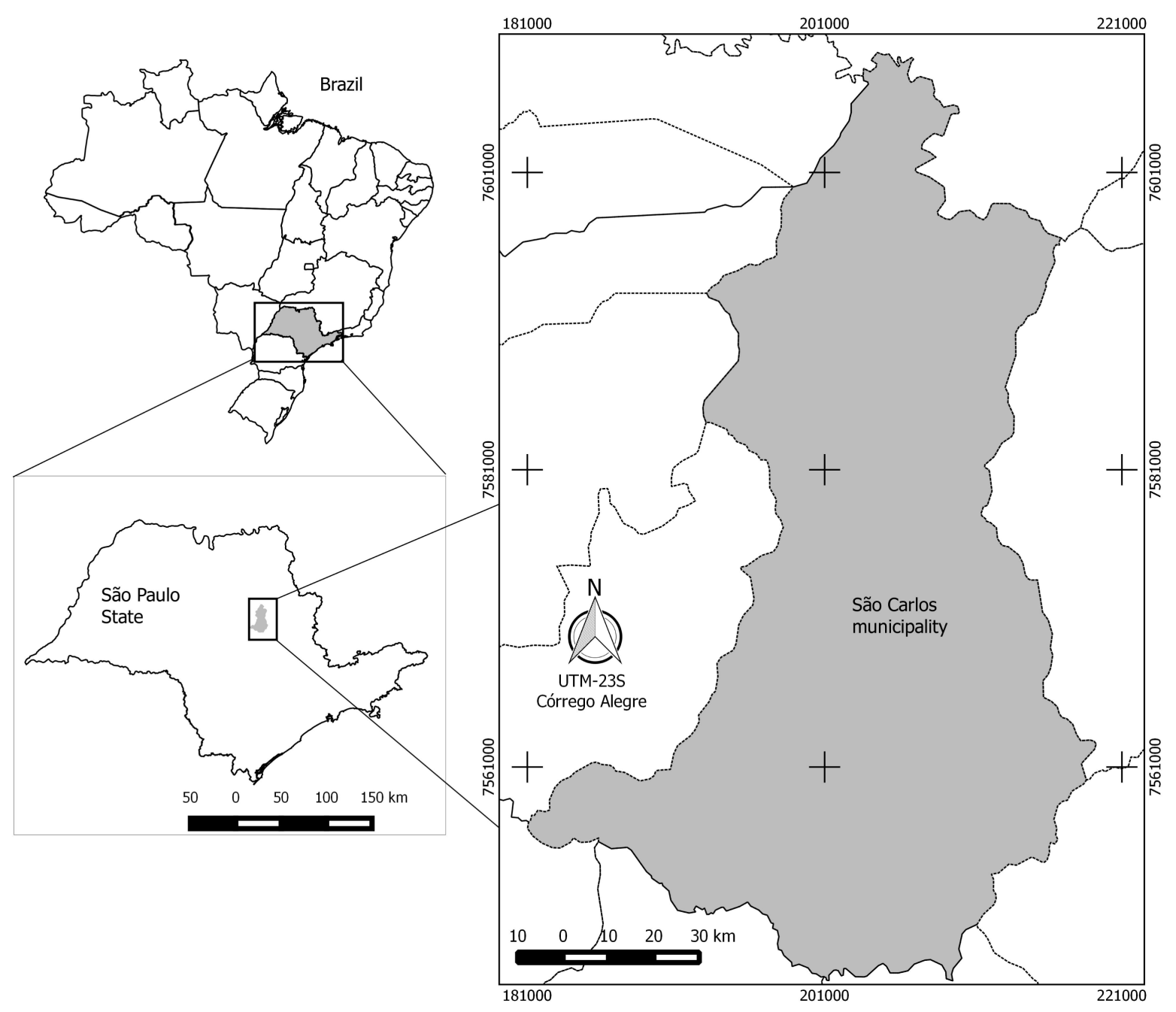

Figure 1. Location of São Carlos municipality, SP, Brazil.

To simplify the spatial and temporal dynamics of landscape trajectories for illustration purposes, three land use classes were defined: Forest (secondary forest, savanna and short-shrub savanna), Agriculture (perennial and annual crops, bare soil, pasture and forestry) and Others (settlements, road networks, industrial complexes, mining areas and water bodies). The spatial representation of trajectories of land use changes for the periods 1965, 1989 and 2014 were obtained based on the IDRISI Selva software command CROSSTAB.

The survey of conservative (Legal Reserves and Areas of Permanent Preservation) and punitive (environmental damages process) strategies to protect natural vegetation on private farmland in São Carlos municipality were based on the Brazilian Forest Code. Legal Reserves (LR) information (spatial distribution, area and establishment period) between 1983 and 2014 was obtained through a geodatabase from the Coordination of Biodiversity and Natural Resources-Environmental Secretary of the State of São Paulo. The Areas of Permanent Preservation (APPs) information (spatial distribution and area) was obtained through topographic maps from the Geographic and Cartographic Institute [10]. Areas of Permanent Preservation thematic maps were overlaid with a forest coverage map, resulting in quantitative data to estimate the total APPs percentage area.

The environmental damages processes from 2003 to 2014 were obtained through documents registered in the Coordination of Environmental Inspection-Environmental Secretary of the State of São Paulo.

\section{Results and Discussion}

The recent release of forest cover change estimates for Brazil provides an opportunity to assess variable forest 
transitions and explore implications in terms of promoting sustainability. The trajectory of forest loss in Brazil between 2000 and $2010\left(236,600 \mathrm{~km}^{2}\right)$ was mostly due to the expansion of agricultural activities, representing $65 \%$ of total deforestation in the period. In the corresponding period, the expansion of pasture areas accounted for the other $35 \%$ of deforestation, totaling $127,200 \mathrm{~km}^{2}$ of areas of the Amazon or the Atlantic Forest. Particularly, between 2010 and 2012, there was an increase in the processes of land use and cover in Brazil, where changes in the landscape reached $3.5 \%$ of the country. The expansion of the agricultural frontier has intensified, with the deforestation of an area of $77,520 \mathrm{~km}^{2}$ (68\% of total deforestation), while the expansion of planted pastures accounted for $28 \%$ of deforestation, or $32,120 \mathrm{~km}^{2}$ [13].

Natural landscape conversion for anthropogenic use or changing management practices has also transformed a large proportion of São Paulo province's land surface. By clearing Atlantic forest, practicing subsistence agriculture, intensifying sugar-cane production and expanding urban centers, human actions are changing the province's landscape in significant ways [14]. In a similar way, patches of tropical savanna (cerrado vegetation) are continuously under threat due edge effects and also to the following land use types around these remnants: pasture, annual crop areas, perennial crop areas, sugar cane cultivation areas, forestry areas, settlements, road networks and industrial complexes [15].

Landscape change through human influence for São Carlos municipal territory shows that natural vegetation has been replaced by intensifying sugar-cane production and expanding urban area. A legal proceedings survey for São Carlos municipal territory only involving deforestation activities from 1991 to 2000 identified the loss of 1121.62 ha of natural vegetation, roughly $100 \mathrm{ha} /$ year. This total of natural and semi natural vegetation area was estimated at $14.1 \%$ of the municipal territory's total area [16]. The natural vegetation occupied $28 \%$ (31,776.4 ha) of the São Carlos municipality total area in 2012 [17].

Multi-temporal information regarding the processes and patterns of land use change is particularly useful in cultural landscapes where changes have been rapid. Furthermore, this information provides the opportunity to understand how historical land use changes affect environmental and socio-economic sustainability. The spatial and temporal aspects of land use and cover change trajectories for five decades (1965, 1989 and 2015) of the study area are illustrated in Figure 2. The time series of remote sensing data revealed that land use and cover changes do not take place in a progressive and gradual way in São Carlos municipality. A period of rapid and abrupt change (1965-1989) was followed by recovery of forest areas (1989-2014) for a similar quantitative condition existing as of 1989 .

For agricultural land use and cover, pasture areas, perennial and annual crop areas, bare soil and forestry areas makes up the largest percent with 54.17\%, 66.60\% and 63.26\% respectively for 1965, 1989 and 2014. Forest areas, including secondary forest, savanna and short-shrub savanna, make up the next largest land use and occur predominantly in areas with greater relief. Forest area decreased during the first period of study from $41.75 \%$ to $26.91 \%$ (1965-1989) but then reached a subsequent recovery in the proportion of forested area (26.39\%) during the second period (1989-2014). The class other land uses (including settlements, road networks, industrial complexes, mining areas and water bodies) increased during all period (4.08\%, 6.49\% and 10.35\% respectively for 1965, 1984 and 2014) (Figure 2). The expansion of the urban area in the 50-year period reflects rapid and significant municipal population growth, with a population around 70,000 in 1965 and a total population of 238,958 inhabitants in 2014 and the potential to reach 241,389 in 2015 (http//www.cidades.ibge.gov.br/).

Change trajectories between the years 1965, 1989 and 2014 were compared on a pixel-by-pixel basis to examine possible land use change. Land use classification trajectories for 1965-1989-2014 are shown in Figure 3, where "F" refers to Forest, "A" to Agriculture, and "O" to Others.

Around forty percent of the landscape remained in the same land use class from 1965 to 2014, with 9237.78 ha (8.14\%) of stable forest cover (F-F-F), 34,715.52 ha (30.58\%) of stable agriculture use (A-A-A) and 1901.43 ha $(1.67 \%)$ of stable other areas class (O-O-O) in the last five decades. For the total forest area existing in 2014 (26.39\%), which remained in the same type of use (9237.78 ha/8.14\%/F-F-F), the remaining area (18.25\%) refers to forest area converted to other uses and which returned to a forest condition (3.63\%/F-A-F and F-O-F), the conversion of agricultural areas to forest area (13\%:15\%/A-F-F; A-A-F and A-O-F) and the conversion of other types of land use to forest area (1\%:46\%/O-F-F; O-A-F and O-O-F) (Figure 3).

The total agricultural area existing in 2014 (63.26\%), around 34,715.52 ha, (30.58\%/A-A-A) remained in the same type of use. Agriculture took the place of 30,173.49 ha (27.11\%) of forest from 1965-2014 (1.4\%/F-F-A; $22.87 \% / \mathrm{F}-\mathrm{A}-\mathrm{A}$ and $0.23 \% / \mathrm{F}-\mathrm{O}-\mathrm{A})$. Agriculture took the place of 729.54 ha of other land uses from 1965-2014 (O-F-A/0.19\%; O-A-A/0.20\% and O-O-A/0.25\%) (Figure 3). 


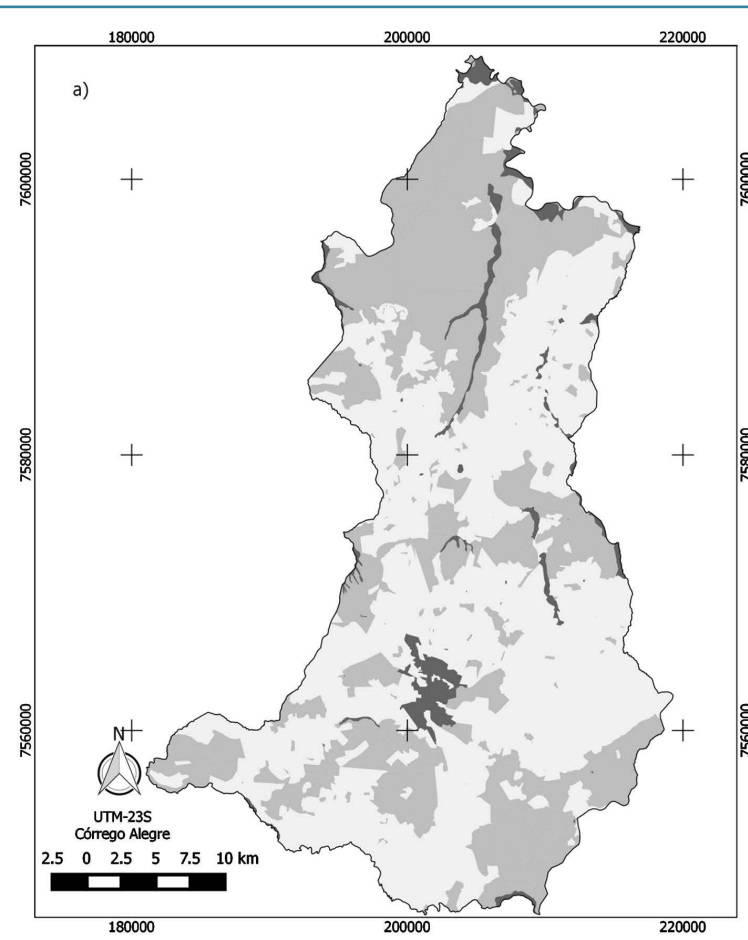

(a)

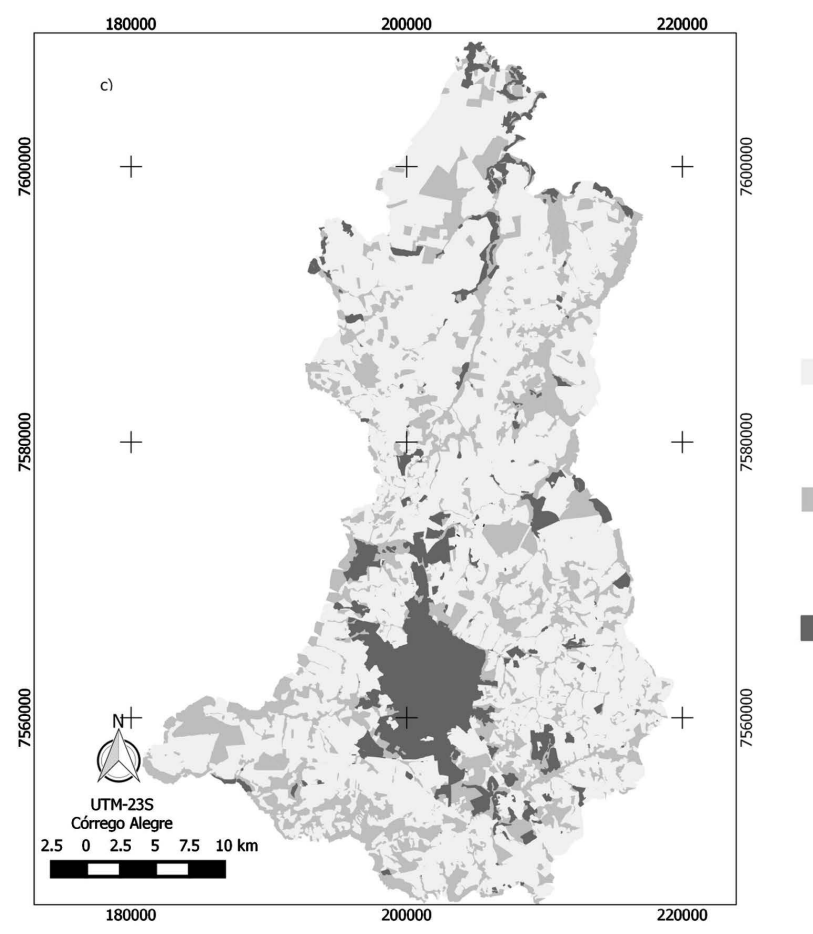

(c)

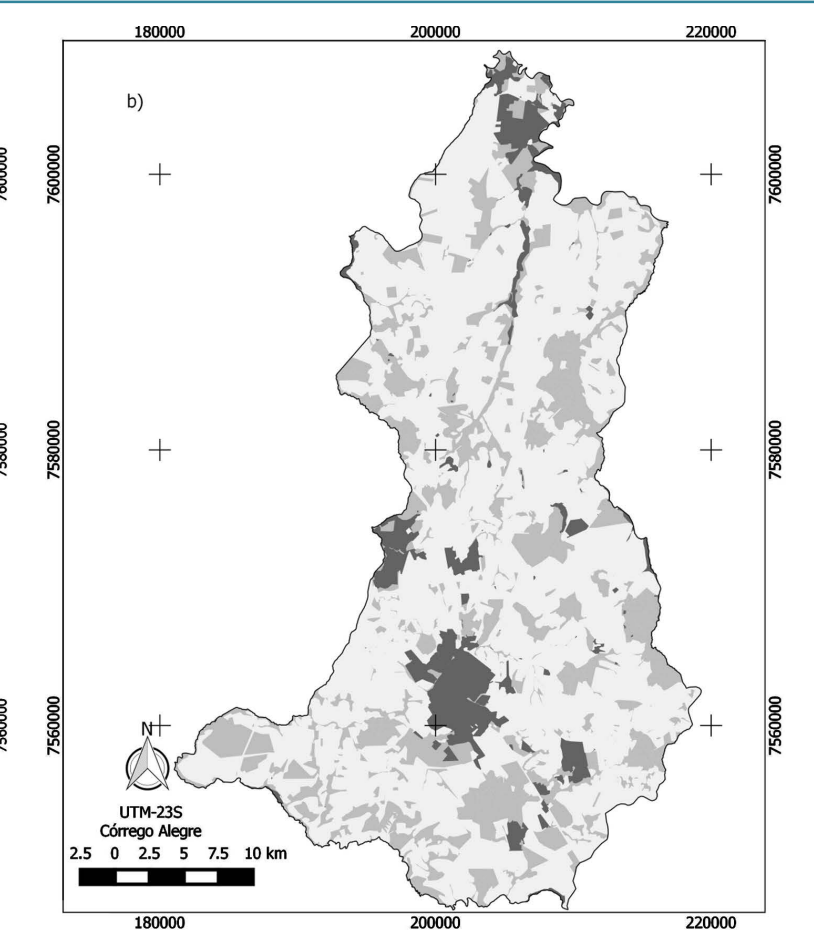

(b)

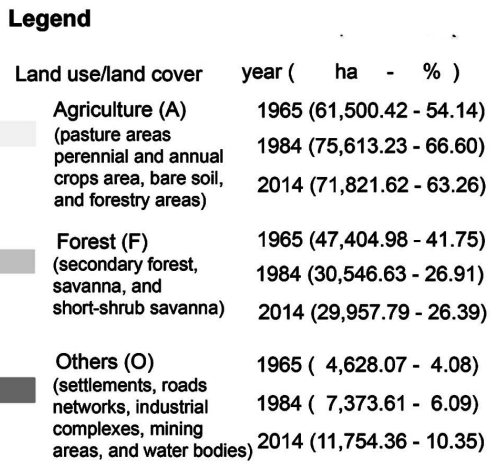

Figure 2. Kind of land use and cover (Agriculture, Forest and Others) changes in São Carlos municipality for (a) 1965, (b) 1989 and (c) 2014.

The other land uses class in 2014 replaced 3.41\% of areas occupied by forest in 1965 (F-F-O/0.95\%; F-A-O/1.20\% and F-O-O/1.26\%). Other land uses took the place of 5647.41 ha of agriculture land use from 


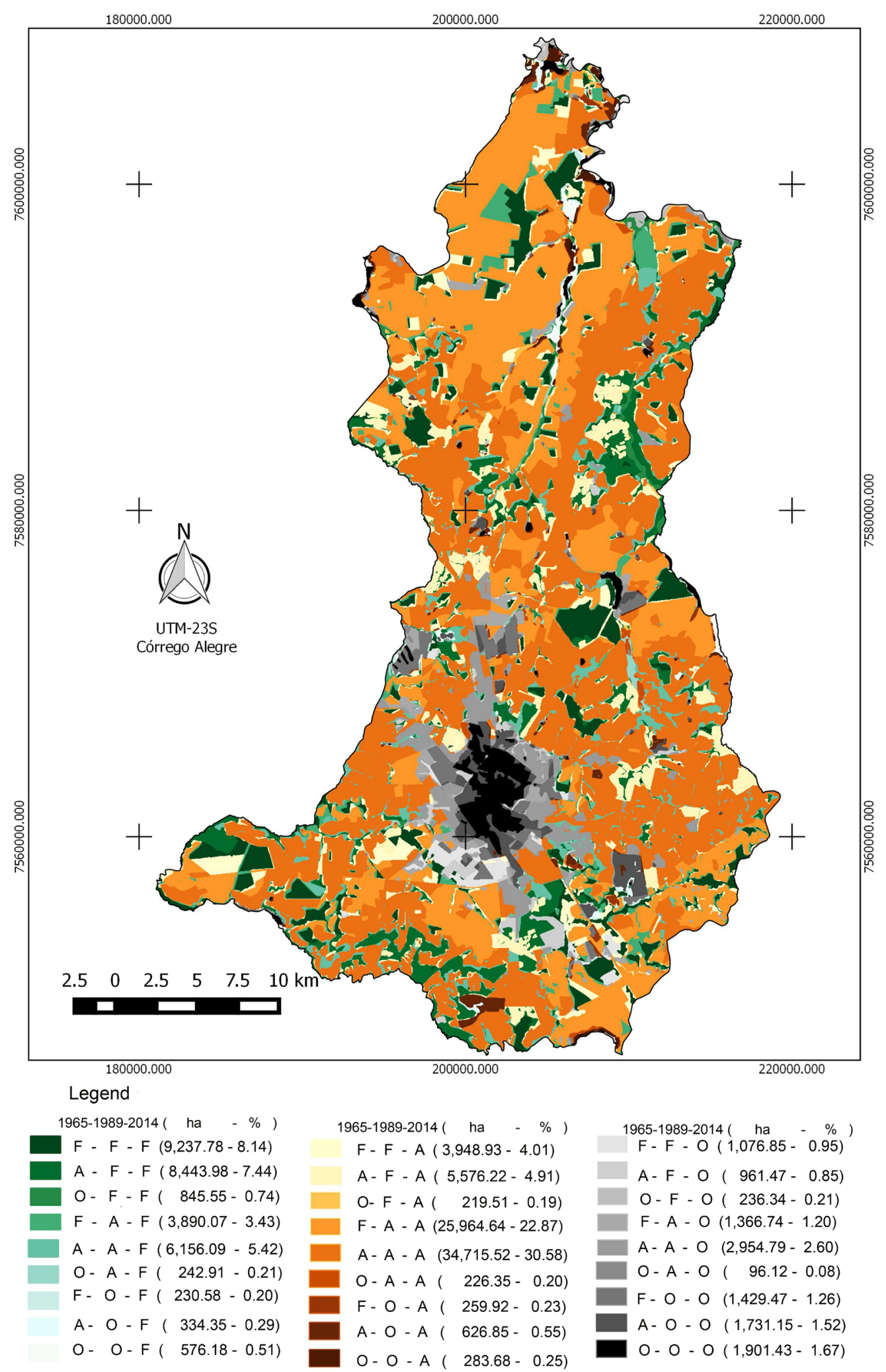

Figure 3. Land use classification trajectories for 1965-1989-2014 at São Carlos municipality, with "F" refers to forest, "A" to agriculture, and "O" to other use classes (settlements, road networks, industrial complexes, mining areas and water bodies). 
1965-2014 (A-F-O/0.85\%; A-A-O/2.60\% and A-O-O/1.52\%) (Figure 3).

During the first period (1965-1989), the main trajectories were dominated by deforestation transitions that led to the increase of agricultural land as a result of logging practices. In this first period, nearly 15\% of São Carlos municipality was replaced by agriculture or other uses (Figure 2). It seems that these changes were induced by organized human activities that coincided with the local practical situation. Deforestation was caused by either permanent or sudden forces that took place in the municipal territory.

In the municipal territory, the period of random change, coincidentally also of a large amount of deforestation, coincides with the Brazilian National Alcohol Program (ProAlcohol), characterized by trade policies, which opened up the economy to international trade in favor of alcohol production. This program was created in 1975 to concentrate all national efforts to increase alcohol production and use. During phase one (1975-1979), government policies searched to facilitate both distillery expansion and higher conversion rates in the gasoline-alcohol mixture. In phase two, from 1980, the Brazilian government authorized and subsidized a vast expansion of sugar cane production capacity and industrial investment in mills and in distilleries [18].

The study area suffered serious forest losses as a result of agricultural expansion in the 50-year period, which brought great damage to local biodiversity and to local residents. Agricultural land use in 2014 occupies nearly $64 \%$ of the total study area. Around $30.58 \%$ of the study area remained in the same type of land use (A-A-A) since 1965. About 5\% of agricultural land use of the study area in 1965 has undergone a transition for forest land use use in 1989, returning again for agricultural land use in 2014. Agriculture replace of $27.11 \%$ of forest land use (F-F-A/4.01\%; F-A-A/22.87\%, and F-O-A/0.23\%), and $0.64 \%$ of other land uses (O-F-A/0.19\%; O-A-A/0.20\%, and O-O-A/0.25\%) during 1965-2014 (Figure 4(a)).

From Figure 4(b), it can be seen that most of the contiguous forest land use in the north and southeast region in 1965 was replaced (F-F-A/3.48\% and F-A-A/22.87\%) by agriculture. Only 8.14\% of São Carlos municipality was occupied by forest area that had remained for five decades.

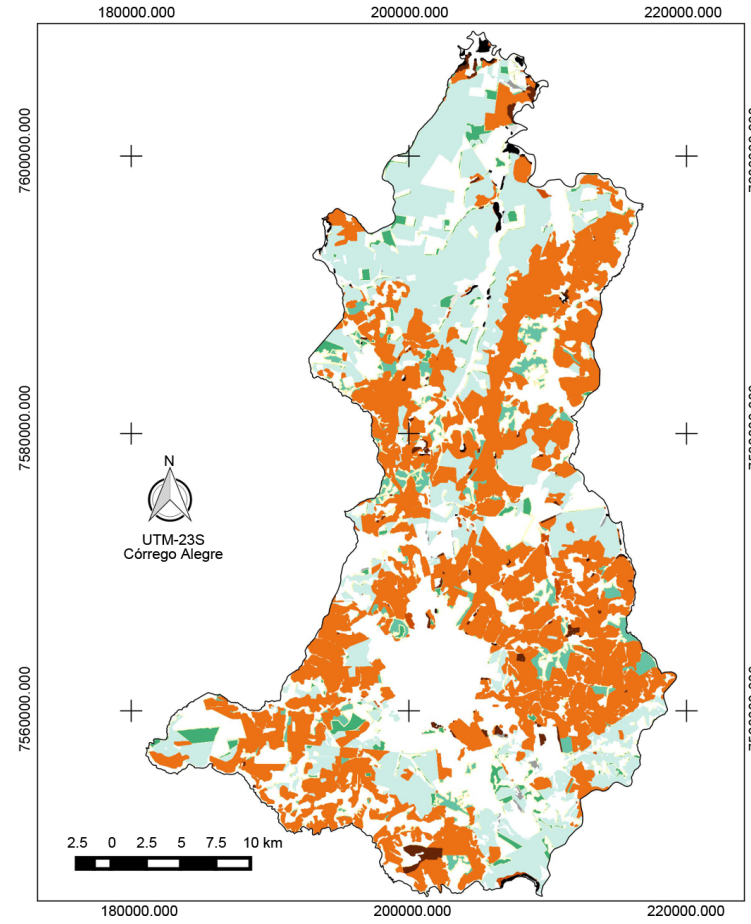

(a)

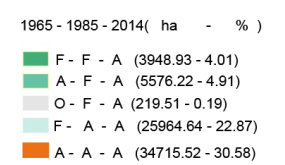

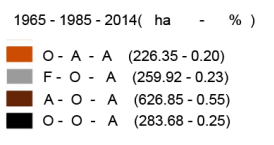

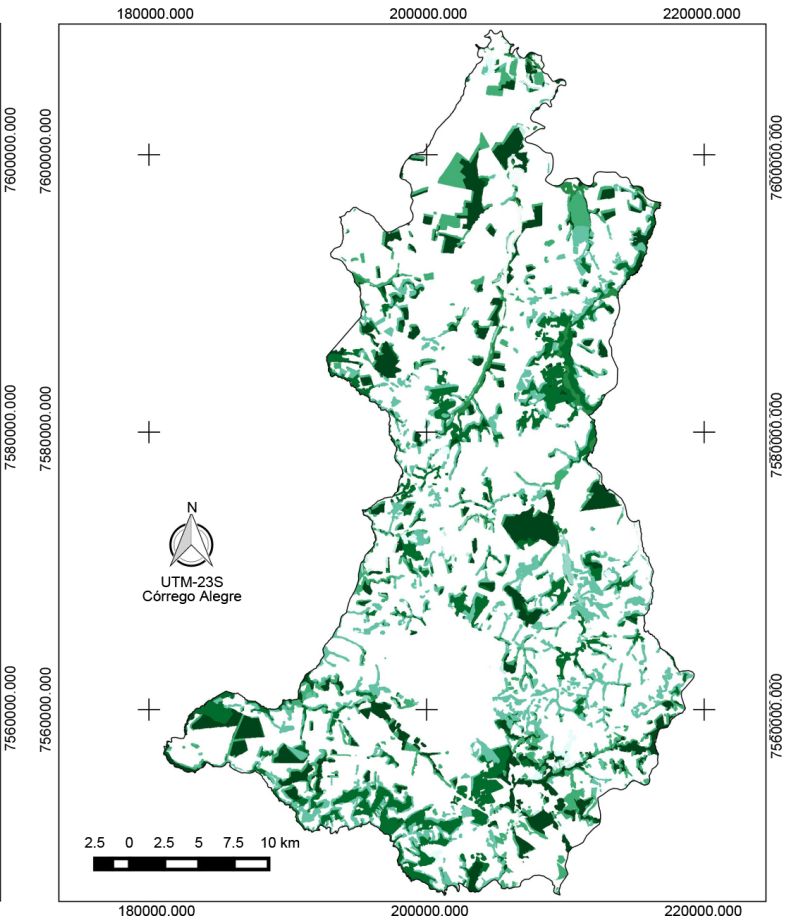

(b)

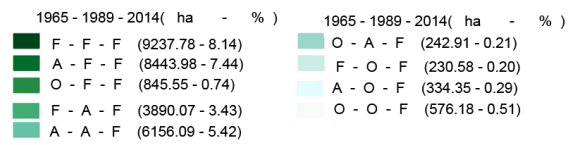

Figure 4. Agriculture (a) and (b) forest land use trajectory during 1965 to 2014 at São Carlos municipality, with "F” refers to forest, "A" to agriculture, and "O" to other use classes. 
In 2014, the vegetation in legally protected areas in São Carlos municipality occupied 23,085.91 ha (20.6\%) with 20,968.24 ha (18.50\%) of Legal Reserves and 2387.67 ha (2.10\%) of Areas of Permanent Preservation with vegetation (Figure 5).

The amount of remaining vegetation (6871.58 ha/5.78\%) of São Carlos municipality not legally protected and was more susceptible to anthropic occupation. This unprotected natural vegetation has come become under increased conversion pressure from agriculture to compensate for the lost production associated with the restrictions that apply to Areas of Permanent Preservation and Legal Reserves [19].

Governance and law enforcement were important tools for re-conversion of current agricultural land to forest land in São Carlos municipality. The increase in vegetation area was associated with the establishment of Legal Reserves between 1999 and 2014 (Figure 6). The absence of established Legal Reserves from 2010-2014 may be explained by the reduction of legal requirements for conservation in Brazil's Forest Code [19].

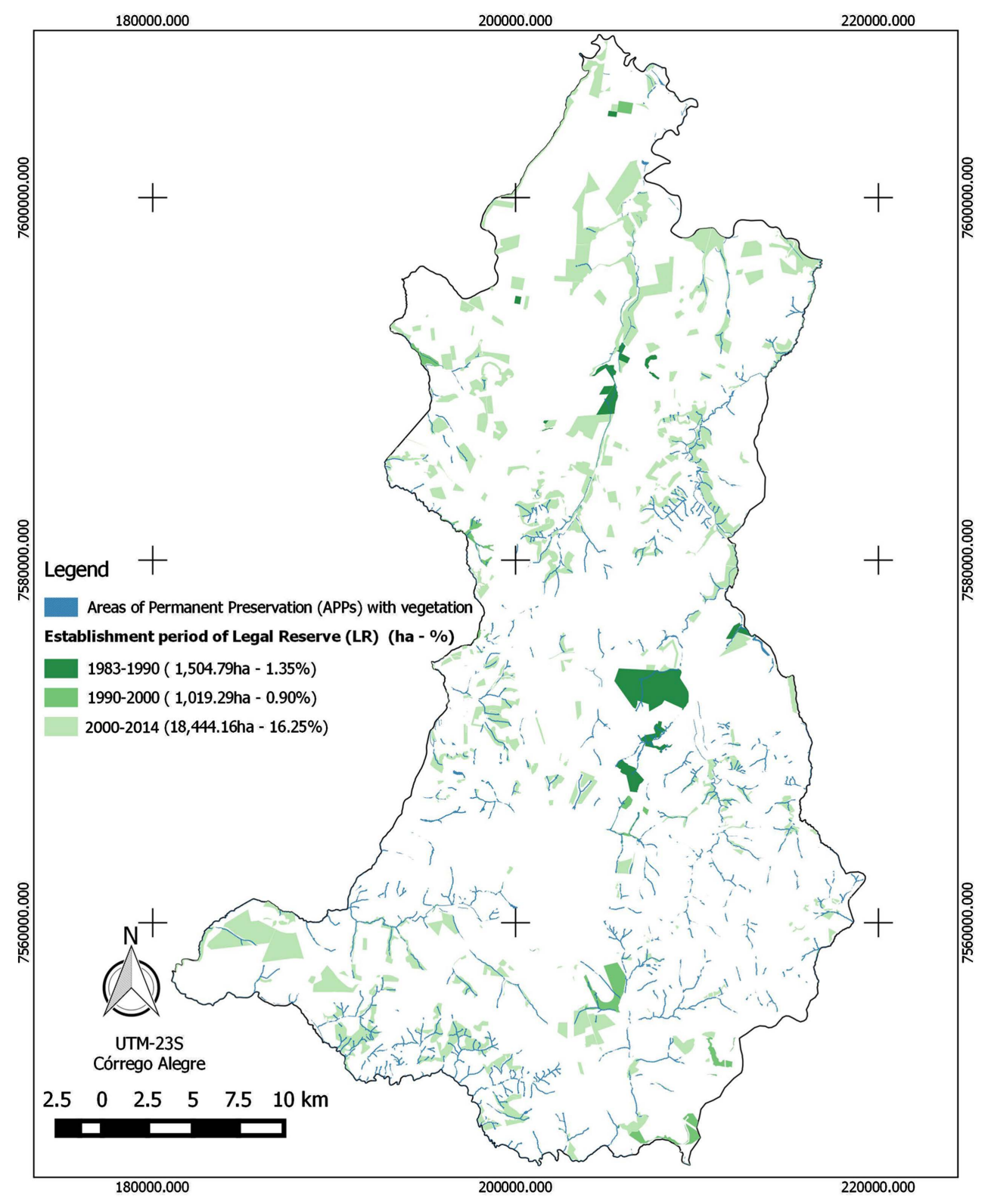

Figure 5. Specific categories of legally protected areas (ha and \%) in São Carlos municipality: Legal Reserves (LR) and Areas of Permanent Preservation (APPs). Establishment period (1983-2014) of Legal Reserve. 


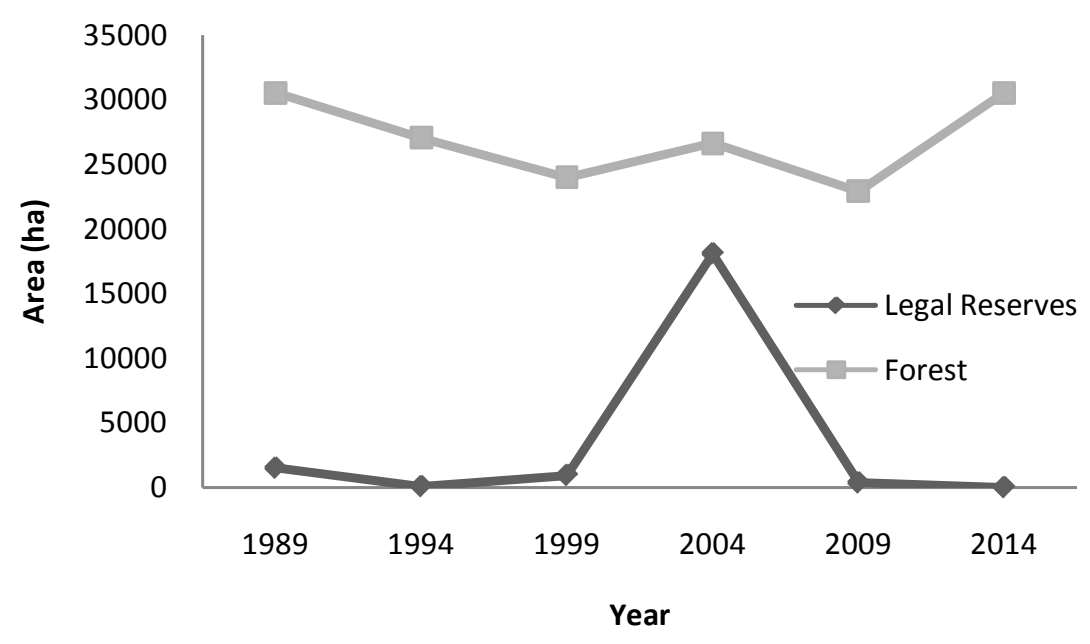

Figure 6. Establishment period of Legal Reserves and Forest trajectory areas in São Carlos municipality between 1989 and 2014.

The Brazilian Forest Code is the central piece of legislation regulating land use and management on private property. The substitutive Forest Code (Law $\mathrm{N}^{\circ} 12.651$, 25th May 2012) reduced requirements for protection of natural vegetation on private farmland and allowed protection of natural vegetation outside the farm [20].

The establishment of Legal Reserves and Areas of Permanent Preservation can be considered a preventive environmental practice that requires not only defense against imminent damages, but that also encourages the protection and regular use of natural resources. Furthermore, the Brazilian legislation has punitive mechanisms related to the denouncement of environmental damage.

In São Carlos municipality, the forest area increase between 2010 and 2014 (Figure 6) can be associated with the actions of environmental damage repair. There were 126 occurrences in this period (2010-2014), compared to a total of 194 occurrences between 2003 and 2014.

The punitive approach legally penalizes the infringer and requires repair of effects of environmental damage, for example, when damage related deforestation is identified, an official document (Environmental Recovery Commitment Agreement/TCRA) is signed by the infringer and environmental agencies to formalize measures to be implemented for native vegetation restoration.

Accurate land use change trajectories analysis was useful for devising future changes for landscape sustainability and planning strategies for the territorial municipality. A very important process to estimate is the rate, pattern and type of land cover change trajectories in order to predict changes for sustainable development.

Such changes often caused by the interaction of climatic and land use factors and have an important impact on ecosystem processes. However, the land cover changes for the São Carlos municipality data-deforestation, changes in the extent of cultivated lands and urbanization-are processes of conversion that are not strongly affected by interannual climatic variability.

\section{Conclusions}

The present level of local biodiversity in São Carlos municipality is related to 29,957.49 ha (26.39\%) of forested area, set by a change in landscape structure with a reduction in size, an increase in the number and in the isolation of fragments and a loss of landscape connectivity (Figure 4(b)).

The transition from forest for agricultural and urban land use is a recognized process of global occurrence. However, at a regional and local level that it is possible to know and act on the balance of this transition. The cultural landscape related to the municipal territory of the State of São Paulo, as well as other cities of Brazil are experiencing a transition and increasing loss of natural habitats resulting from the interaction between nature, development, and society. This scenario makes it essential to know the amount of the remaining natural capital of a cultural landscape, as well as the implementation of strategies to control or minimize the loss of habitat and local biodiversity.

The question is what amount of forest area should be remained under current trends and policies given trade-offs 
with economic development and agriculture to ensure environmental sustainability of cultural landscape.

According a review based on species of temperate areas, the amount can be considered a threshold of around $30 \%$ of remaining habitat, above which the effects of biodiversity loss would be due to habitat loss [21] [22]. Below this threshold, there may be a drastic effect on the spatial distribution of the habitat. This threshold has no empirical support, as shown by results obtained in tropical regions reporting fragmentation effects on the habitat loss process [23]. However, there is evidence that landscapes with less than $30 \%$ of natural habitat tend to have only small fragments and be isolated, thus supporting impoverished communities and different taxonomic groups [24] [25].

Thus, the threshold of $30 \%$ could be considered as the lower limit of a forest that has a landscape managed by man to balance economic use and biodiversity conservation [26]. However, even considering the area values of Legal Reserve and Permanent Protection Areas (Figure 5), the municipality of São Carlos does not have a forest cover area above this threshold.

São Carlos municipality has achieved a reduction in landscape deforestation. However, this profit is not yet assured. Our study suggests that the Forest Code will allow additional deforestation due to local development actions. Fortunately, government initiatives are aligning to assist conservation efforts in expanding legally protected areas in São Carlos municipality. These implemented regional strategies can support the complete set of ecosystem services and improve managed landscape sustainability.

\section{Acknowledgements}

Financial support was provided by the Coordination for the Improvement of Higher Education Personnel (CAPES).

\section{References}

[1] Lambin, E.F., Geist, H.J. and Lepers, E. (2003) Dynamics of Land-Use and Land-Cover Change in Tropical Regions. Annual Review of Environment and Resources, 28, 205-241. http://dx.doi.org/10.1146/annurev.energy.28.050302.105459

[2] Foley, J.A., Defries, R., Asner, G.P., Bonan, G., Carpenter, S.R., Chapin, F.S., Coe, M.T., Daily, G.C., Gibbs, H.K., Helkowski, J.H., Holloway, T., Howard, E.A., Kucharik, C.J., Monfreda, C., Patz, J.A., Prentice, I.C., Ramankutty, N. and Snyder, P.K. (2005) Global Consequences of Land Use. Science, 309, 570-574. http://dx.doi.org/10.1126/science.1111772

[3] DeFries, R.S., Foley, J.A., and Asner, G.P. (2004) Land-Use Choices: Balancing Human Needs and Ecosystem Function. Frontiers in Ecology and the Environment, 2, 249-257. http://dx.doi.org/10.1890/1540-9295(2004)002[0249:LCBHNA]2.0.CO;2

[4] Mather, A.S. and Needle, C.L. (1998) The Forest Transition: A Theoretical Basis. Area, 30, 117-124. http://dx.doi.org/10.1111/j.1475-4762.1998.tb00055.x

[5] Rudel, T.K., Coomes, O.T., Moran, E., Achard, F., Angelsen, A., Xu, J. and Lambin, E. (2005) Forest Transitions: Towards a Global Understanding of Land Use Change. Global Environmental Change, 15, 23-31. http://dx.doi.org/10.1016/j.gloenvcha.2004.11.001

[6] Borri, M.S. and Vozenilek, V. (2014) Remote Sensing and Land Use/Land Cover Trajectories. Journal of Geophysics \& Remote Sensing, 3, 123.

[7] Skalos, J. and Engstova, B. (2010) Methodology for Mapping Non-Forest Wood Elements Using Historic Cadastral Maps and Aerial Photographs as a Basis for Management. Journal of Environmental Management, 91, 831-843. http://dx.doi.org/10.1016/j.jenvman.2009.10.013

[8] Soares, J.J., Silva, D.W. and Lima, M.I.S. (2003) Current State and Projection of the Probable Original Vegetation of the São Carlos Region of São Paulo State. Brazilian Journal of Biology, 63, 527-536. http://dx.doi.org/10.1590/S1519-69842003000300019

[9] IBGE (2014) Resolution No. 2 of August 26, 2014. Estimates of the Population for the States and Municipalities with Reference Date on July 1, 2014. Official Federal Gazette, Brazil 28 August, Section 1, 115.

[10] IBGE (1971) Topographic Maps: Topographic Mapping of Brazil. Scale 1:50.000. Rio de Janeiro.

[11] Crosta, A.P. (1992) Remote Sensing Digital Image Processing. IG/UNICAMP, Campinas.

[12] Moreira, M.A. (2011) Remote Sensing Fundamentals and Application Methods. 4th Edition, UFV, Viçosa, MG.

[13] IDS (2015) Indicators of Sustainable Development: Brazil. Coordination of Natural Resources and Environmental Stu- 
dies. IBGE, Rio de Janeiro.

[14] Ribeiro, M.C., Mettzger, J.P., Martensen, A.C., Ponzoni, F.J. and Hirota, M.M. (2009) The Brazilian Atlantic Forest: How Much Is Left, and How Is the Remaining Forest Distributed? Implications for Conservation. Biological Conservation, 142, 1141-1153. http://dx.doi.org/10.1016/j.biocon.2009.02.021

[15] Durigan, G., Siqueira, M.F. and Franco, G.A.D.C. (2007) Threats to the Cerrado Remnants of the State of São Paulo, Brazil. Scientia Agricola (Piracicaba. Braz.), 64, 355-63. http://dx.doi.org/10.1590/S0103-90162007000400006

[16] Cintra, R.H.S., Santos, J.E., Moschini, L.E., Pires, J.S.R. and Henke-Oliveira C. (2006) Qualitative and Quantitative Analysis of Environmental Damages through Instauration and Registers of Lawful Documents. Brazilian Archives of Biology and Technology, 49, 989-999. http://dx.doi.org/10.1590/S1516-89132006000700017

[17] Bertini, M.A., Fushita, A.T. and Lima, M.I.S. (2015) Vegetation Coverage in Hydrographic Basins in the Central Region of the State of São Paulo, Brazil. Brazilian Journal of Biology, 75, 709-717. http://dx.doi.org/10.1590/1519-6984.21713

[18] Oliveira, J.A. (2002) The Policymaking Process for Creating Competitive Assets for the Use of Biomass Energy: The Brazilian Alcohol Programme. Renewable and Sustainable Energy Reviews, 6, 129-140. http://dx.doi.org/10.1016/S1364-0321(01)00014-4

[19] Sparovek, G., Berndes, G., Barreto, A.G.O.P., Leoname, I. and Klug, F. (2012) The revision of the Brazilian Forest Act: Increased Deforestation or a Historic Step towards Balancing Agricultural Development and Nature Conservation? Environmental Science \& Policy, 16, 65-72. http://dx.doi.org/10.1016/j.envsci.2011.10.008

[20] Soares-Filho, B., Rajão, R., Macedo, M., Carneiro, A., Costa, W., Coe, M., Rodrigues, H. and Alencar, A. (2014) Cracking Brazil's Forest Code. Science, 344, 363-364. http://dx.doi.org/10.1126/science.1246663

[21] Andrén, H. (1994) Effects of Habitat Fragmentation on Birds and Mammals in Landscape with Different Proportions of Suitable Habitat: A Review. Oikos, 71, 355-366. http://dx.doi.org/10.2307/3545823

[22] Fahrig, L. (2003) Effects of Habitat Fragmentation on Biodiversity. Annual Review of Ecology, Evolution and Systematic, 34, 487-515. http://dx.doi.org/10.1146/annurev.ecolsys.34.011802.132419

[23] Develey, P.F. and Metzger, J.P. (2006) Emerging Threats to Birds in Brazilian Atlantic Forests: The Roles of Forest loss and Configuration in a Severely Fragmented Ecosystem. In: Laurance, W.F. and Peres, C.A., Eds,, Emerging threats to Tropical Forests, University of Chicago Press, Chicago, 269-290.

[24] Martensen, A.C., Pimentel, R.G. and Metzger, J.P. (2008) Relative Effects of Fragment Size and Connectivity on Bird Community in the Atlantic Rain Forest: Implications for Conservation. Biological Conservation, 141, $2184-2192$. http://dx.doi.org/10.1016/j.biocon.2008.06.008

[25] Metzger, J.P., Martensen, A.C., Dixo, M., Bernacci, L.C., Ribeiro, M.C., et al. (2009) Time-Lag in Biological Responses to Landscape Changes in a Highly Dynamic Atlantic Forest Region. Biological Conservation, 142, 1166-1177. http://dx.doi.org/10.1016/j.biocon.2009.01.033

[26] Metzger, J.P. (2010) The Forest Code has Scientific Basis? Brazilian Journal of Nature Conservation, 8, 92-99. 